\title{
Preliminary investigation for beneficiation of Indonesian
}

\section{manganese ore}

\author{
N Jafar ${ }^{1}$, S R Nurhawaisyah ${ }^{1}$, S Widodo ${ }^{2}$, N Asmiani ${ }^{1}$, H Harwan ${ }^{1}$, F Firdaus ${ }^{1}$ \\ ${ }^{1}$ Department of Mining Engineering, Faculty of Industrial Technology, Universitas Muslim Indonesia 90231, \\ Indonesia \\ ${ }^{2}$ Mining Engineering Department, Faculty of Engineering, Hasanuddin University 90245, Indonesia \\ Corresponding author e-mail: nurliah.jafar@umi.ac.id
}

\begin{abstract}
In this study, manganese ore sample collected from Palludda village, Barru Regency, South Sulawesi Province, Indonesia was investigated. Processing is required to make the ore viable and profitable. The focus of this study is determining the distribution of the assay values among various sizes of manganese ore. On the other hand, to obtain information about its optimum size, which contains the main mineral in a large portion with a small portion of the gangue which consisted in the manganese ore, which defined as the liberation of its main mineral from the gangue. Size assay analysis of manganese ore is of prime importance through which much information can be obtained. The fractioning and chemical analysis are conducted to measure the assay of various minerals and also their distribution in different size fractions. It indicated that manganese and hematite are valuable mineral present, whereas $\mathrm{Pb}$ and $\mathrm{Zn}$ are the trace element compositions and the gangue mineral that present in the ore is silica. Based on the assay value of each size fraction of manganese ore showed that the maximum liberation of manganese mineral could be obtained at the size range of -20 to +48 mesh. Therefore, further investigation studies on this manganese ore are needed.
\end{abstract}

Key words: Beneficiation, Fractioning, Manganese ore

\section{INTRODUCTION}

Manganese ore is an important raw material in steel industry in the form of Ferro-manganese. It can also be used for non-metallurgical purposes, e.g., for the manufacturing of dry batteries, animal feed, plant fertilizer [1] and chemical industries. Furthermore, manganese is also used in the manufacture of drier for paints and varnishes. It has important application in ceramic and glass industry as coloring agent [2]. Therefore, manganese ore has greater importance from industrial point of view. The high demand of manganese ore in the world is estimated to increase every year.

The manganese content in earth's crust is $0.11 \%$, which is the twelfth most abundant element and has an atomic number 25 (the symbol $\mathrm{Mn}$ ). The main minerals present in the manganese are the oxide types, such as pyrolusite $\mathrm{MnO}_{2}$, hausmannite $\mathrm{Mn}_{3} \mathrm{O}_{4}$ and manganite $\mathrm{MnO}(\mathrm{OH})$. Manganese is also found in several minerals, such as pink rhodochrosite $\left(\mathrm{MnCO}_{3}\right)$, rhodonite $\left(\mathrm{MnSiO}_{3}\right)$, wad and alabandite $(\mathrm{MnS})$ [3]. Minerals such as rhodochrosite, rhodonite and hausmannite are often replaced by pyrolusite. Pyrolusite containing 63.2\% Mn is the most common manganese mineral [4].

Each type of manganese ore has an economic optimum particle size, which will depend on many factors, including the extent to which the values are dispersed in the gangue. They must be initially unlocked or liberated before the subsequent separation process can be undertaken. Beneficiation technology as applied to manganese ores is similar to that for iron ores [5]. Previous studies have been conducted for some iron ores in South Sulawesi province $[6,7]$. The methods of beneficiating of ores normally depend upon many factors. The factors, influence the selection of a beneficiation technique are ore mineralogy, chemical composition, density difference between various minerals, surface properties, magnetic and electrostatic properties [8]. Various techniques most widely used in manganese ore beneficiation in the world are gravity concentration, magnetic separation and froth flotation [8].

In Indonesia, manganese ore are found in Tasikmalaya (West Java), Central Java, North Sumatra, Aceh, Maluku, Nusa Tenggara and Sulawesi. Some areas have abundant manganese reserves, while other areas still need further research. Based on data from the Geological Agency in 2016, total manganese resources in Indonesia amounted to $61,631,820$ tons of ore and 28,295,896 tons of metal. While manganese reserves in the form of ore amounted to 87,236,536 tons and in the form of metals amounted to 43,134,791 tons. Until now, manganese ore in Indonesia that have been mined and utilized are located in Tasikmalaya (West Java), Kulon Progo (Yogyakarta) 
and East Nusa Tenggara with varying quality of manganese grade.

Manganese ore in Indonesia, especially in South Sulawesi Province, has yet to be fully utilized. One of the right steps after mining low grade manganese ore is beneficiation (the process of increasing manganese content so that it meets the requirements to be used as value-added raw materials). In the beneficiation process, one of the important variables is particle size. Therefore, this study was conducted as a preliminary study to determine the effect of particle size on changes in mineral content of the manganese ore constituents before the beneficiation process.

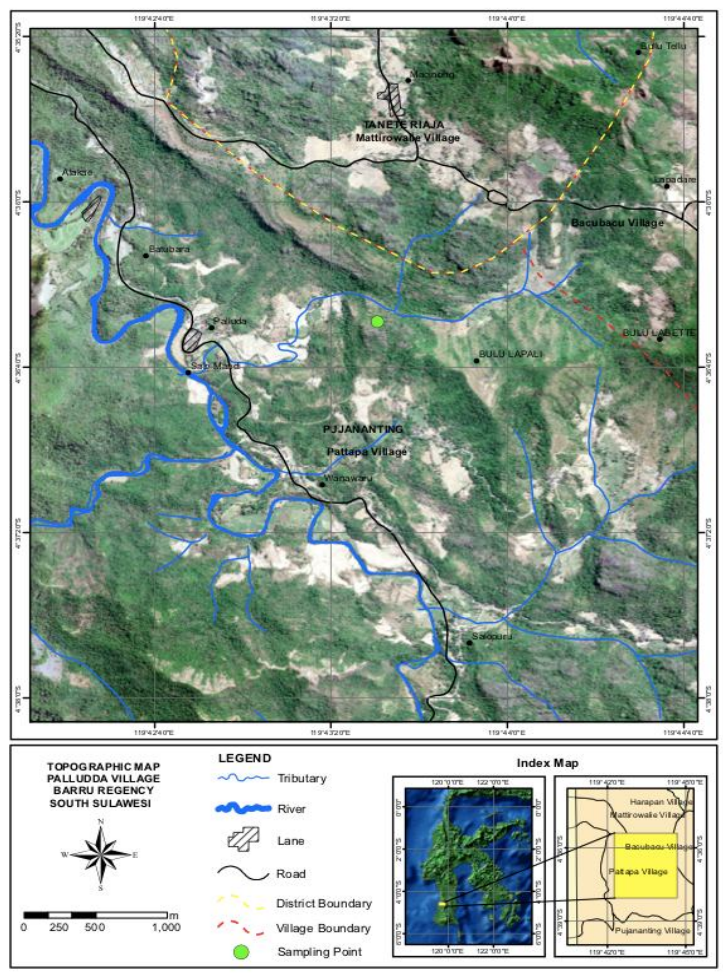

Figure 1. The map of study area and sampling point of manganese ore

\section{MATERIALS AND METHODS}

Manganese ore was collected from Palluda Village, Barru Regency, South Sulawesi Province. Ore outcrop is separated from the parent rock, and then ore were reduced manually in terms of size using hammer to reduce it in order to suit for laboratory jaw crusher feed. Almost $5 \mathrm{~kg}$ ore was crushed using jaw and roll crushers in laboratory, to create $1.0 \mathrm{~cm}$ in product size. The roll crusher product was ground for improving its liberation using a ball mill. Manganese ore sample was fractioned into five sizes using dry sieving on laboratory sieve shaker. Undersize ore after being sieving was weighed and then all the mass fractions obtained were sent for analysis. The size fractions used in this study were +20 , $-20+48,-48+80,-80+100$, and $-100+200$ mesh. These ore separate, coned and quartered to obtain representative samples prior to the analysis which were stored in plastic bags. Figure 1 shows map of study area and its sampling point location.

The assay value of each size fraction of manganese sample is determined by chemical analysis. This is usually called size assay analysis. It is of prime importance through which much information can be obtained i.e., distribution of the values among various sizes will be known. Chemical analysis of various size fractions were performed by X-Ray Fluorescence (XRF). It was conducted in representative samples at Analysis and Mineral Processing Laboratory of the Hasanuddin University. Figure 2 shows stage and procedure of sample preparation in this study.

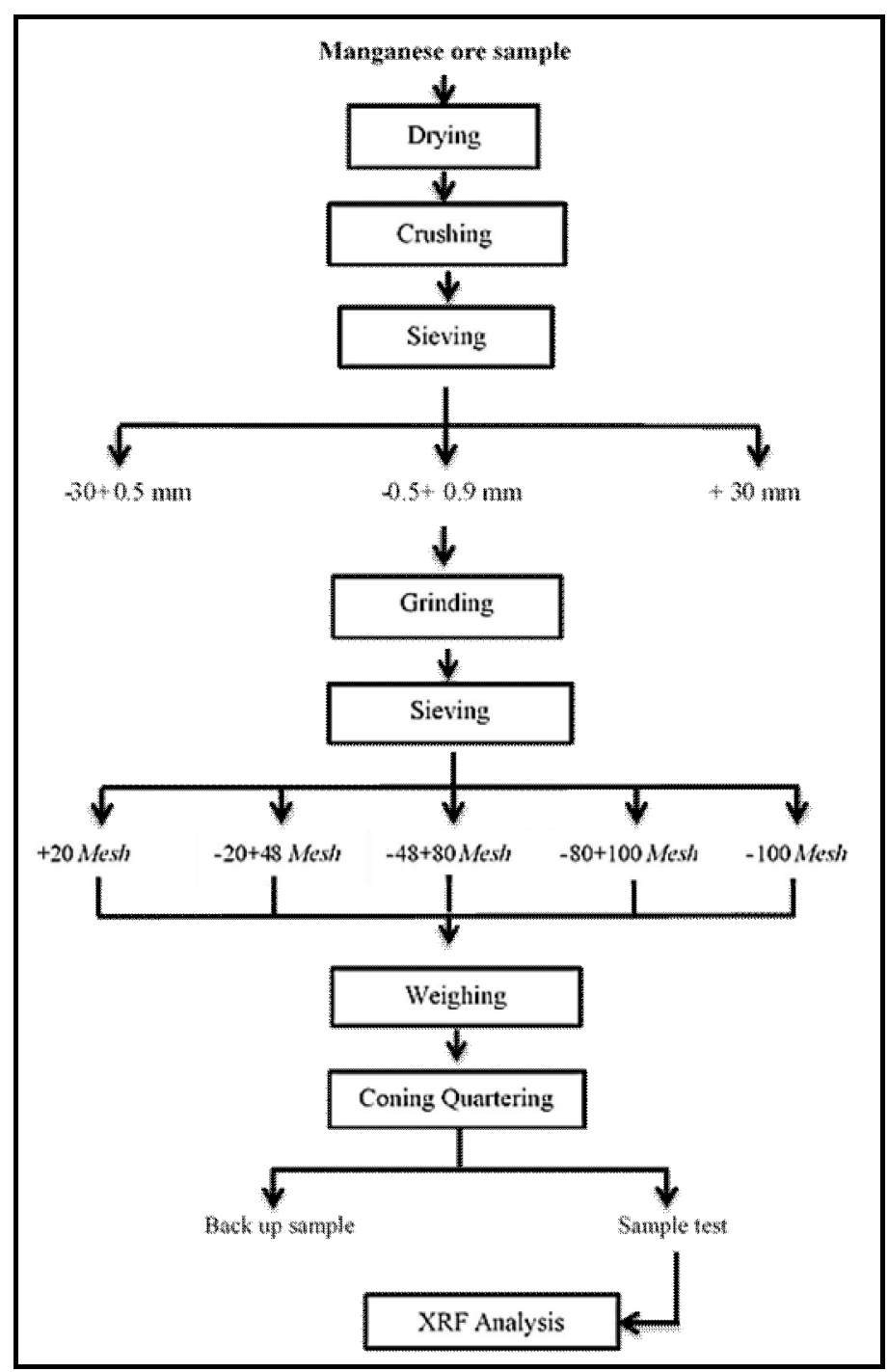

Figure 2. The stage and procedure of sample preparation 


\section{RESULTS AND DISCUSSIONS}

Size assay analysis of manganese ore of each size fraction is given in Table 1. Size assay analysis also includes percentages of $\mathrm{Fe}_{2} \mathrm{O}_{3}, \mathrm{PbO}, \mathrm{ZnO}$ dan $\mathrm{SiO}_{2}$. $\mathrm{Pb}$ and $\mathrm{Zn}$ were found as trace element compositions in the manganese deposits of Palludda Village, Barru Regency, South Sulawesi Province [9]. $\mathrm{SiO}_{2}$ is a gangue mineral of manganese ore with small amount.

Table 1. Size assay analysis of manganese ore sample.

\begin{tabular}{ccccccc}
\hline $\begin{array}{c}\text { Size } \\
(\mathrm{mesh})\end{array}$ & $\mathrm{Wt} \%$ & $\mathrm{MnO} \%$ & $\mathrm{Fe}_{2} \mathrm{O}_{3} \%$ & $\mathrm{PbO} \%$ & $\mathrm{ZnO} \%$ & $\mathrm{SiO}_{2} \%$ \\
\hline+20 & 9.47 & 39.77 & 55.74 & 1.96 & 1.51 & - \\
\hline$-20+48$ & 21.49 & 48.32 & 40.42 & 2.66 & 1.87 & 3.31 \\
\hline$-48+80$ & 13.48 & 47.78 & 40.02 & 2.84 & 2.06 & 5.46 \\
\hline$-80+100$ & 1.40 & 35.27 & 27.60 & 1.85 & 1.33 & 5.20 \\
\hline$-100+200$ & 11.07 & 32.07 & 28.06 & 1.66 & 1.25 & 6.78 \\
\hline
\end{tabular}

Figure 3 and 4 shows manganese and hematite distribution among various sizes of the ground manganese ore sample.

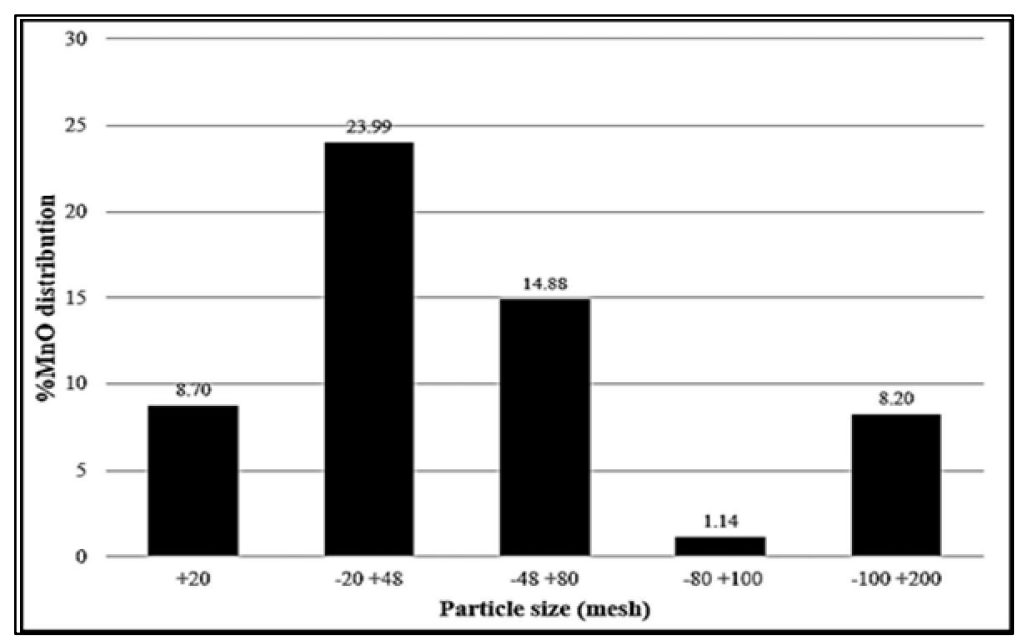

Figure 3. Manganese distribution in ground manganese ore.

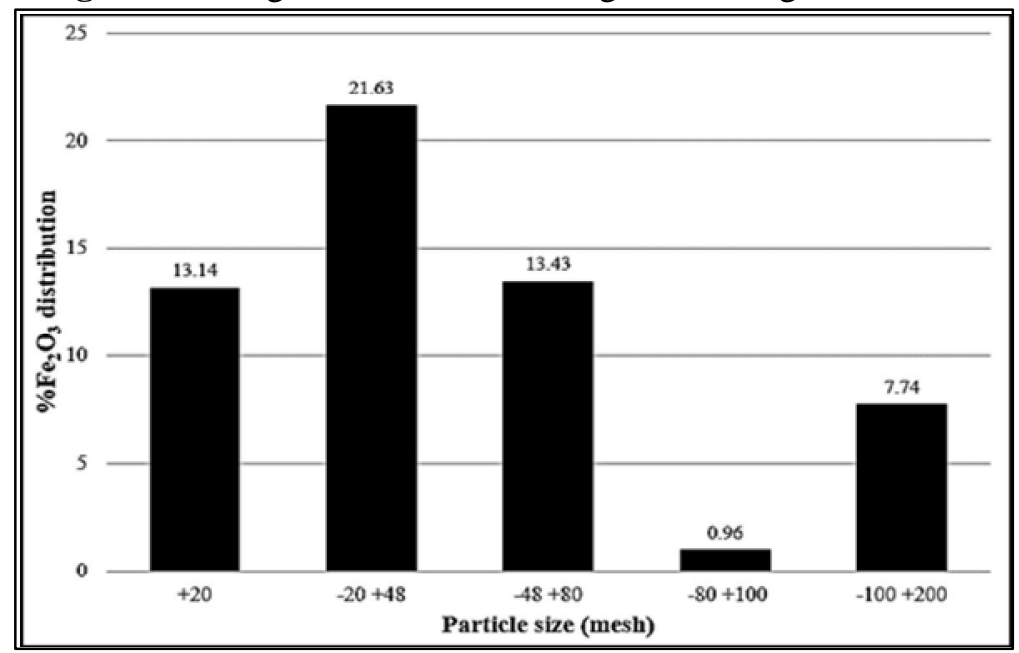

Figure 4. Hematite distribution in ground manganese ore.
Table 1 shows that percentage of manganese has a greatest value of $48.32 \%$ which lies in the size range of $-20+48$ mesh and it is further observed that it gradually decreased above or below this size. Calculated manganese distribution values in Figure 3 reveals that $23.99 \%$ manganese is distributed in coarse size fraction of -20+48 mesh and only $8.20 \%$ manganese is distributed in fine size fraction of $-100+200$ mesh. It was further observed that the percentage of hematite is high sufficiently at this size range, i.e. $40.42 \%$. Hematite distribution values in Figure 4 reveals that $21.63 \%$ hematite is distributed in size fraction of $-20+48$ mesh. Percentage of hematite decreases with decrease in size of the particle except in $-100+200$ mesh. Calculated hematite distribution value in Figure 4 reveals that $7.74 \%$ hematite is distributed in $-100+200$ mesh size fraction and $0.96 \%$ is distributed in $-80+100$ mesh size fraction.

\section{CONCLUSION}

Preliminary investigation of manganese ore of Palluda Village showed that the percentage of manganese and hematite are dominate in manganese ore whereas the silica present in the ore as the gangue mineral. Based on chemical analysis of various size fractions, it was found that the optimum mesh of grind size for the manganese ore is $-20+48$ mesh. Therefore, further investigation studies on this manganese ore are needed to obtain the valuable elements of $\mathrm{Mn}$ and $\mathrm{Fe}$ and then be utilized in the ferromanganese industry.

\section{ACKNOWLEDGEMENT}

This study was supported by Department of Mining Engineering, Faculty of Industrial Technology, Universitas Muslim Indonesia. The authors wish to thank Hasanuddin University for samples analysis.

\section{REFERENCES}

[1] U.S. Geological Survey 2015 Mineral Commodity Summaries 2015 US Geological Survey

[2] Sontakkey V A, Mohanram I and Aruna A 2016 Utilization of Manganese Dump Rejects of Central India Region for Industrial Applications Report Indian Bureau of Mines

[3] Fuerstenau M C, Han K N and Miller J D 1986 Flotation Behavior of Chromium and Manganese Minerals In Proc. Arbiter Symposium Advances in Mineral Processing 289-307

[4] Zhang W and Cheng C Y 2007 Manganese Metallurgy Review. Part I: Leaching of Ores/Secondary Materials and Recovery of Electrolytic/Chemical Manganese Dioxide Hydrometallurgy 89(3-4) 137-159

[5] Mehdilo A, Irannajad M and Hojjati-Rad M R 2013 Characterization and Beneficiation of Iranian 
N Jafar et al., International Journal of Emerging Trends in Engineering Research, 9(2), February 2021, 66 - 69

Low-Grade Manganese Ore Physicochemical Problems of Mineral Processing 49

[6] Sufriadin, Widodo S, Trianto, M 2019 Beneficiation of Lateritic Iron Ore from Malili Area, South Sulawesi, Indonesia Using Magnetic Separator IOP Conf. Series: Materials Science and Engineering 619 (1), $1-8$.

[7] Sufriadin, Widodo S, and Mantung M, 2019 Beneficiation Study of Iron Ore from Pakke Area of Bontocani Subdistrict, Bone Regency of South Sulawesi, Indonesia Using Roasting and Magnetic Separation Methods International Journal of Engineering and Science Applications 2, 67-71.

[8] Ahmad I 2016 Preliminary Investigations for The Upgradation of North Waziristan Manganese Ore Work Design Science, Technology and Development 35(1) $22-25$

[9] Nur I and Widodo S 2015 Mineralogy Study and Geochemistry of Paludda Regional Manganese Deposition, Barru District, South Sulawesi In Proceeding, National Seminar Of 8th Archipelago Academia-Industry Linkage 15-16 October 2015; Grha Sabha Pramana 2015 Oct 18. Department of Geological Engineering. 